\title{
European perspective on the links among public investments, banking and sovereign risk
}

\author{
EVŽEN KOČENDA, Ph.D.*
}

Conference keynote**

https://doi.org/10.3326/pse.42.2.3

\footnotetext{
* Support from the GAČR grant No. P402/12/G097 (DYME) is acknowledged. The usual disclaimer applies.

${ }^{* *}$ Received: January 16, 2018

Accepted: January 18, 2018

A keynote speech given at the conference "Public Sector Economics 2017 - Public investment: catalyst for sustainable growth" organized by the Institute of Public Finance and Friedrich-Ebert-Stiftung in Zagreb on
} \author{
November 3, 2017.

\section{Evžen KOČENDA} \\ Institute of Economic Studies, Charles University, Faculty of Social Sciences, Opletalova 26, 11000 Prague, \\ Czech Republic \\ Department of Econometrics, Institute of Information Theory and Automation, Pod Vodárenskou věží 4, \\ 18208 Prague, Czech Republic \\ Center for Economic Studies, Leibniz Institute for Economic Research at the University of Munich, Poschin- \\ gerstr. 5, 81679 Munich, Germany \\ Leibniz-Institute for East and Southeast European Studies, Landshuter Str. 4, 93047 Regensburg, Germany \\ e-mail: evzen.kocenda@fsv.cuni.cz \\ ORCiD: 0000-0003-4110-1169
}




\section{INTRODUCTION}

Sovereign risk has become a pressing issue for the European Union (EU) in the aftermath of the global financial crisis (GFC) of 2007-2008. At the same time, the link between sovereign risk and the banking sectors of EU countries emerged, as several EU governments had to intervene to stabilize their banking sectors during the severe turmoil of the GFC (Correa et al., 2014). After all, based on the ECB Statistical Warehouse data, on average around 9\% of total assets of EU banks consists of sovereign bonds of EU countries.

The sovereign risk and banking sector nexus in the EU has important implications for public finances in EU member states. When governments see banks in their countries in need of help, they might decide to prepare a bail-out package to save the financial institutions. Such a solution might become a burden on public finances: a government must borrow funds and at the same time there is less fiscal space for public investments. One outcome is that sovereign risk might increase. On the other hand, a bail-out of the banking system can be considered a cost-effective option if it prevents the economy from collapsing. Arguably, an economic collapse would negatively affect public finances to an even greater extent.

Brůha and Kočenda (2018) analyze the potential nexus between sovereign risk and the characteristics of banking sectors in the EU, including their quality and performance. Their analysis allows general conclusions to be drawn about the whole of the EU as well as those specific to regional groups. It also offers potential policy implications regarding public finances and public investments in EU countries.

\section{BACKGROUND}

In general there are three channels linking sovereign risk and banking sectors. First, circumstances might require governments to act as lenders of last resort when domestic banks are in dire need of recapitalization (Gerlach, Schulz and Wolff, 2010). Second, banks' business operations - and more specifically, their adjustments of balance sheets - might have severe implications for the availability of short-term funding in a particular country (Adrian and Shin, 2009), for a shortage of credit can contribute to higher sovereign risk. Third, Brůha and Kočenda (2018) argue for the existence of a corporate credit risk channel. In general, higher dynamics of bank credit is inversely related to sovereign risk as it is a sign of economic expansion. However, the abundance of the bank credit provided might also channel some funding to projects that are destined to fail (Mehrez and Kaufmann, 2000). When the inefficiency of such projects materializes, governments might see their tax revenues declining and unemployment benefits increasing. Firms in charge of failing projects are forced to shrink their workforce and at the same time the banks, which have provided the now non-performing loans, are supposed to utilize loan loss provisions created in case such situations should arise. This development might decrease the fiscal health of a particular country and contribute to an increase in its sovereign risk. 
The existing literature on the sovereign risk and banking sectors nexus in the EU is somewhat limited. Gerlach, Schulz and Wolff (2010) report that larger banking sectors are associated with higher sovereign risk. Gómez-Puig, Sosvilla-Rivero and Singh (2015) find that contagion can spread from banking sectors to sovereigns. Brůha and Kočenda (2018) document the existing link between banking sector quality and sovereign risk in the whole of the EU over 1999-2014.

Finally, a sizable strand of literature provides an assessment of the link between sovereign risk and public finances. For the Eurozone, Hallerberg and Wolff (2008) report that public deficits significantly increase risk premia. Bernoth, von Hagen and Schuknecht (2012) find evidence that government debt affects yield spreads. Using a theoretical model, Corsetti et al. (2013) show that sovereign risk may amplify the effects of cyclical shocks to public finances. Finally, for a sample of 22 advanced economies, Poghosyan (2014) determines that an increase in bond yields is positively linked to an increase in the government debt-to-GDP ratio.

Based on the above evidence there are good reasons for the links between sovereign risk, banking sector quality, and public investments.

\section{RECENT EVIDENCE}

Brůha and Kočenda (2018) use data on sovereign risk and banking sector characteristics for 27 EU countries in the sample period from 1999 to 2014. They proxy sovereign risk with four indicators: (i) the government bond yield spread, (ii) sovereign credit default swap (CDS) spread, (iii) expert opinion-based country risk score, and (iv) sovereign credit rating. The state of banking sectors in the EU countries is characterized by three systemic indicators (size, depth and foreign bank penetration) and three indicators related to the performance of banking sectors (efficiency, stability and degree of competition). Their analysis of the sovereign risk and banking sector nexus is performed for the whole of the EU along with various country groups, for the pre-crisis (1999-2007) and the post-crisis (2008-2014) periods. The analysis is based on the Bayesian method for panel data with country fixed effects to minimize time-invariant endogeneity (Wooldridge, 2002; Greene, 2003) to deliver a valid inference under some uncertainty (Daniels and Hogan, 2014; Gelman et al., 2014).

Brůha and Kočenda (2018) do find evidence for the link between the efficiency of banking sectors and sovereign risk in the EU. They show that less efficient and larger banking sectors are linked to higher sovereign risk and the result is robust as it holds irrespective of which sovereign risk measure and which country subgroup is chosen. Other links are specific to a country group or a time period. However, higher foreign bank penetration and higher competition - two signs of diversified banking sector - are associated with greater financial stability of the banking sector as they are linked with lower sovereign risk after the GFC. 


\section{IMPLICATIONS}

The results of Brůha and Kočenda (2018) suggest certain implications related to public investments and public finances in the EU. First, after the GFC, the size of banking sectors of the EU countries was started to be perceived by market participants as an upper bound for potential bailouts. And indeed, several EU countries have been forced to conduct them. The finding provides a direct implication for the fiscal space of the EU governments. Arguably, a bailout might jeopardize public investments as government's indebtedness increases in the case of a bank rescue.

Second, the link between sovereign risk and banking sector is relevant also from the private investment perspective. Investors on stock markets consider countries and their banking sectors interconnected, partly, because of the government guarantees towards domestic banks (Correa et al., 2014). Moreover, when domestic sovereign risk becomes pronounced, foreign creditors first assess the sovereign risk and then they consider the creditworthiness of the firms in the economy (Cooper and Argyris, 1998). From the side of the banking sector, its lower stability implies that fewer funds are available for potential investments.

Finally, the structural break occurring around the onset of the GFC is relevant. The results of Brůha and Kočenda (2018) imply that financial markets reassessed the linkage between banking sector characteristics and sovereign risk. This yields support for the "wake-up call hypothesis" associated with the GFC. The large repricing of the sovereign risk after the GFC quite likely affected public investments via the implementation of austerity policies in the EU countries. 


\section{REFERENCES}

1. Adrian, T. and Shin, H. S., 2009. Money, Liquidity, and Monetary Policy. American Economic Review, 99(2), pp. 600-605. https://doi.org/10.1257/aer. 99.2.600

2. Bernoth, K., Von Hagen, J. and Schuknecht, L., 2012. Sovereign Risk Premiums in the European Government Bond Market. Journal of International Money and Finance, 31(5), pp. 975-95. https://doi.org/10.1016/j.jimonfin. 2011.12.006

3. Brůha, J. and Kočenda, E., 2018. Financial stability in Europe: Banking and sovereign risk. Journal of Financial Stability (forthcoming). https://doi.org/ 10.1016/j.jfs.2018.03.001

4. Cooper, C. L. and Argyris, C. (eds.), 1998. The Concise Blackwell Encyclopedia of Management. Wiley-Blackwell.

5. Correa, R. [et al.], 2014. Sovereign Credit Risk, Banks' Government Support, and Bank Stock Returns around the World. Journal of Money, Credit and Banking, 46(s1), pp. 93-121. https://doi.org/10.1111/jmcb.12080

6. Corsetti, G. [et al.], Sovereign risk, fiscal policy, and macroeconomic stability. The Economic Journal, 123(566), F99-F132. https://doi.org/10.1111/ecoj.12013

7. Daniels, M. J. and Hogan, J. W., 2014. Bayesian Methods in: G. Molenberghs [et al.], eds. Handbook of Missing Data Methodology. Chapman and Hall/CRC.

8. Gelman, A. [et al.], 2014. Bayesian Data Analysis. Boca Raton: CRC Press.

9. Gerlach, S., Schulz, A. and Wolff, G. B., 2010. Banking and Sovereign Risk in the Euro Area. CEPR Discussion Paper, No. 7833. Available at: <https:// cepr.org/active/publications/discussion_papers/dp.php?dpno=7833>

10. Gómez-Puig, M., Sosvilla-Rivero, S. and Singh, M. K., 2015. Sovereigns and banks in the euro area: a tale of two crises. Research Institute of Applied Economics Working Paper, 2015/04 1/52. Available at: <http:/www.ub.edu/irea/ working_papers/2015/201504.pdf>

11. Greene, W., 2003. Econometric Analysis. Upper Saddle River, NJ: Prentice Hall.

12. Hallerberg, M. and Wolff, G. B., 2008. Fiscal institutions, fiscal policy and sovereign risk premia in EMU. Public Choice, 136(3), pp. 379-396. https:// doi.org/10.1007/s11127-008-9301-2

13. Mehrez, G. and Kaufmann, D., 2000. Transparency, Liberalization, and Banking Crisis. World Bank Policy Research Working Paper, No. 2286. Available at: <http://documents.worldbank.org/curated/en/429731468739157817/pdf/multi-page.pdf $>$

14. Poghosyan, T., 2014. Long-run and short-run determinants of sovereign bond yields in advanced economies. Economic Systems, 38(1), pp. 100-114. https:// doi.org/10.1016/j.ecosys.2013.07.008

15. Wooldridge, J., 2002. Econometric Analysis of Cross Section and Panel Data. Cambridge, MA: The MIT Press. 